\title{
Balance-of-payments-constrained economic growth in Brazil
}

\author{
Crescimento econômico limitado pela balança \\ de pagamentos no Brasil
}

FREDERICO GONZAGA JAYME JR. $* * * *$

RESUMO: Este artigo aplica o modelo de restrição de balança de pagamentos de Thirlwall ao crescimento econômico brasileiro no período 1955-98, usando a técnica de cointegração. De acordo com Thirlwall (1979) e MacCombie e Thirlwall (1994), as diferenças no crescimento econômico de longo prazo entre os países podem ser explicadas por uma teoria do crescimento econômico induzida pela demanda. O modelo é testado na economia brasileira após a decolagem industrial em 1955 até 1998, usando a técnica de cointegração e uma representação de correção de erro vetorial (VEC) para encontrar as respostas dinâmicas das exportações ao PIB. Os resultados mostram que há uma cointegração positiva entre o crescimento das exportações e o crescimento econômico de longo prazo no Brasil, o que sustenta o fato de fatores externos restringirem o crescimento econômico brasileiro.

PALAVRAS-CHAVE: Restrição de balança de pagamentos; crescimento; economia pós-Keynesiana.

ABSTRACT: This paper applies the Thirlwall's balance-of-payments constraint model to Brazilian economic growth in the period 1955-98, using cointegration technique. According to Thirlwall (1979) and MacCombie and Thirlwall (1994) differences in long-term economic growth among countries can be explained by a demand induced theory of economic growth. The model is tested on the Brazilian economy after industrial take- off in 1955 until 1998 using the cointegration technique and a vector error correction (VEC) representation to find the dynamic responses of exports to GDP. The results show that there is a positive cointegration between growth in exports and long-term economic growth in Brazil, which support the fact external factors constraint Brazilian economic growth.

KEYWORDS: Balance of payments constraint; growth; post Keynesian economics. JEL Classification: E12; O10.

\footnotetext{
* Departamento de Economia do Centro de Desenvolvimento e Planejamento Regional da Universidade Federal de Minas Gerais - CEDEPLAR-UFMG, Belo Horizonte/MG, Brasil. E-mail: gonzaga@cedeplar. ufmg.br.

"I would like to thank Andre Minela, Anwar Shaikh, Chris Weller, Ricardo Ruiz, Lance Taylor, William Milberg and two anonymous referees of this Journal for helpful comments. Remained errors are mine. Scholarship from Capes is grateful acknowledge. Submitted: 20/February/2002; Approved: 7/May/2002.
} 


\section{INTRODUCTION}

The aim of this paper is to test Thirlwall's model of balance-of-payments (BOP) constrained economic growth. This model will be tested on the Brazilian economy after industrial take-off in 1955 until 1998 using the cointegration technique and a vector error correction (VEC) representation to find the dynamic responses of exports to GDP ${ }^{1}$. According to Thirlwall (1979) the dynamic Harrod foreign multiplier, that is, demand-induced growth, determines long-term economic growth. I chose 1955 to begin this study because thereafter, the Brazilian economy faced structural changes as a consequence of import substitution industrialization (ISI) policies. The hypothesis is that Brazil is a good example of a country where external factors constrain economic growth. Therefore, Thirlwall's framework is an efficient instrument for analyzing the pattern of economic growth constrained by an unfavorable balance of payments. Indeed, this is a typical one-gap model similar to the savings and fiscal gap models built by Chenery and Bruno (1962), Taylor (1991, 1994), and others.

The case of Brazil demonstrates that the external gap has a close relationship with both savings and fiscal gaps. Empirically, by admitting rigid coefficients in the production function, several gaps can appear in the economy. Still, the external gap emerges first and leads to the appearance of other gaps. There is a causal relationship. On the one hand, if they intend to attract capital flows in the short-run, governments must stabilize the exchange and inflation rates. This generates fiscal constraints such as increasing financial government spending and raising interest rates. On the other hand, the poor performance in export growth, the high income elasticity of demand for imports, and current account deficits discourage an increase in domestic savings, which in turn generates a savings constraint. Therefore, by working in a partial equilibrium, the external gap contributes to producing both savings and fiscal constraints.

In light of the problems described above, the central claim in this article is that external constraints strongly influence the pattern of economic growth in Brazil. The best-known periods of external breakdown are the 1980s and 1999, but throughout its history Brazil has sought to carry out import substitution industrialization (ISI) in order to avoid the fiscal, external, and savings constraints. The last major attempt was in the middle of the 1970s, and it failed as a consequence of the structural problems related to the strategy of development, the interest-rate shock in 1979, and the breakdown in capital flows during the 1980s. After capital flows resumed in the 1990s, Brazil stabilized its economy and could show some economic growth. Nevertheless, appreciations of the exchange rate, increasing ex-

\footnotetext{
${ }^{1}$ An estimative of the Thirlwall's model for Brazil including data before the 1980's can be found in Thirlwall, Piancastelli and Fernandes (1981). Holland, Canuto \& Xavier (1998) tested a similar model, but with different specifications and aims to Brazilian Economy using cointegration with quarterly data. López and Cruz (2000) tested from 1965 to 1995.
} 
ternal debt, and trade liberalization have left the Brazilian economy highly vulnerable to external forces. Persistent trade and current account deficits confirm this assertion.

Thirlwall's framework can help us to understanding the pattern of Brazilian economic growth in this period because his demand-pull approach demonstrates that increasing returns are a key element of economic development. Thirlwall's model differs, however, from the New Endogenous Growth models, because it shows that aggregate demand and financial constraints are essential determinants of long-run economic growth. In his framework, Thirlwall shows that productive resources are not always fully utilized, and that their supply tends to respond to the demand for them.

The results of this paper support Thirlwall's law in the sense of exports, income elasticities of imports and GDP have a long run relationship. Indeed, from 1955 to 1998 and selected sub periods there is a cointegration between exports and GDP². Also, the cointegrated equation presents statistical significance when exports are considered as independent variable. Nevertheless, the short-run behavior of these variables in the form of a Vector Error Correction (VEC) representation suggests that the causal relation between exports and GDP comes from GDP to exports. Therefore, Thirlwall's law as a sense of an empirical regularity in the long run, under some restrictive assumptions (such as the absence of price effects), is valid for Brazil. The direction of causality, however, is ambiguous, since lag variables of Exports do not present significance in explaining GDP in the VEC representation.

As Alexander and King (1998) argue, it is important to be caution with econometric results in models relating variables such exports and GDP. Indeed, since exports are components of GDP, it is very likeable that the endogeneity of these variables affects the results. Since the way I choose to support the empirical evidence of Balance-of-payments constrained economic growth in Brazil is an econometric analysis, it is valid to stress its scope and limitations. The purpose of this paper is to investigate whether external restrictions affects long run economic growth in Brazil. Therefore, it is clear that the parameters of the equation, as well as its validate have to be taken cautiously, since this model is simple, as well as it intends to look for any balance of payments constraints in Brazilian economy. Other factors, such financial or institutional aspects would require a more sophisticated model.

The structure of this paper is as follows. Section 2 briefly reviews the theoretical literature on economic growth, openness, and BOP constraints, as well as the principal features of the Brazilian economy during the period 1955-98. Thirlwall's model of BOP-constrained growth is presented and developed in section 3 .

\footnotetext{
${ }^{2}$ Several authors argue that if GDP and exports do cointegrate in the long run, Thirwall's law is valid. (Atesoglu, 1993, 1994, 1997; Hieke, 1997; Moreno-Brid, 1998a, López and Cruz, 2000). This essay, however, claims that further tests have to be carried out to confirm this assertion. The test used here is a VEC representation of the variables, so we can check the direction of causality.
} 
In Section 4 I apply the model to the Brazilian Economy. Methodological procedures will also be discussed in Section 4. In Section 5 I conclude that Thirlwall's model does indeed show that external constraints limit Brazil's economic growth.

\section{THE BRAZILIAN ECONOMY IN THE LAST TWO DECADES AND SOME CONSIDERATIONS ON DEVELOPMENT AND TRADE LIBERALIZATION}

The period 1955-1963 is regarded as the time when important structural changes occurred in Brazil as well as the era in which the rhythm of economic growth was robust. After poor economic growth between 1964-1967, Brazil's gross domestic product (GDP) expanded more than 10\% per year from 1968 to 1973 (the so-called Brazilian Economic Miracle). After that, although there was a decrease in the rate of the expansion of GDP, until 1981 the annual growth rate was around $7 \%$. This growth continued until 1973 with a relatively stable inflation rate and a moderate fiscal deficit. After 1974, however, inflation initiated an acceleration process as well as a rhythm of current account and fiscal deficits ${ }^{3}$.

During the 1980s, Brazil and other Latin American countries faced episodes of persistent high inflation and, in some cases, even hyperinflation. Despite several stabilization programs implemented during this decade, inflation was not reduced until 1994. The most striking aspect of price stabilization is that it coincided with the return of Latin American countries to the international capital markets. Thus, the exchange rate came to be used as the key stabilization variable. The 1980s in Brazil were a time when a break in capital inflows was the central cause for high inflation and a low growth rate. In the 1990s, the return of Brazil and other Latin American countries to the international capital markets greatly reduced this constraint because external capital flows increased international reserves. The stabilization plan worked. Brazil showed reasonable rates of economic growth until 1998. Since a current account deficit cannot be financed indefinitely, however, the BOP constraints have to be solved. Therefore, Thirlwall's model can be an efficient framework for analyzing the pattern of economic growth in Brazil.

The 1980s will be remembered as the time when much of the developing world became engulfed in a debt and macroeconomics crises, and when policy makers began their attack on the inward-oriented, import substitution industrialization (ISI) policies of the past. The marriage between neoclassical approaches to stabilization and a market-oriented strategy of development has provided the basis for structural reforms designed to enable recovery and stability in Brazil and other countries. The most striking characteristic of the "Bretton Woods Institutions" is

\footnotetext{
${ }^{3}$ A good study about the period 1974-1979 and the external consequences (II National Plan of development) is found in Castro and Souza (1985).
} 
its uniformity. Wherever "structural adjustment" is attempted, liberalization and outward orientations are the main strategies employed.

Brazil, after more than twenty years of state intervention and ISI policies, faced episodes of hyperinflation and low rates of growth, when its inward-oriented policies came under attack. Although Brazil's internal imbalance was high, the period between 1981 and 1990 presented a nominal trade surplus above US\$ 10 billion. Brazilian exports, valued in current dollars, increased from US\$ 2.7 billion in 1970 to more than US\$ 30 billion at the end of the 1980 s, whereas the value of imports, after reaching a peak of nearly US\$ 23 billion in 1980, oscillated around the level of US\$ 15 billion during the years 1983-88, and in 1990 was still below the level reached at the beginning of the previous decade. After a break in international capital flows in 1982, Brazil started a process of export promotion in order to guarantee better results in the current account, since that deficit could not be financed by external capital flows.

After 1990, however, when the process of openness began in Brazil, imports grew from around US\$ 20 billion in 1990 (almost the same level as in 1980) to more than US\$ 62 billion in 1997. In the same period, exports increased from US\$ 31 billion to US\$ 53 billion, representing only a $7.7 \%$ per year increase, while that for imports was $17 \%$ per year. The consequences were high trade and current account deficits. Meanwhile, there was a surplus in the capital account, which allowed stabilization of the exchange rate (Foreign reserves reached more than US\$ 70 billion in April 1998.) and, consequently, stabilization in price levels ${ }^{4}$. In fact, trade and financial liberalization in a world in which capital flows are accessible allow a faster accumulation of reserves, mainly if it is noted that monetary policy after Brazil's Real Plan (1994) had the explicit objectives of accumulating foreign reserves, and avoiding inflationary pressures.

One of the hypotheses about the poor growth performance in Brazil is related to the external gap, which in turn leads to fiscal and domestic savings gaps ${ }^{5}$. Indeed, while the exchange rate is the key variable for stabilization, the BOP constrains the expansion of demand in a typical Keynesian formulation. As McCombie and Thirlwall (1994, p. 233) point out, "if a country gets into balance-of-payments difficulties as its expands demand before the short-term capacity growth rate is reached, then demand must be curtailed; supply is never fully utilized; investment is discouraged; technological progress becomes less desirable so worsening the balance of payments still further, and so on. A vicious circle is started."

The Brazilian economy is an apt example of this vicious circle. Although the exchange rate seems not to lead to an inflationary bias, as in the recent past, growth in GDP remains low. The other side of stabilization is an extraordinary increase in

\footnotetext{
${ }^{4}$ Real exchange rate in Brazil had been appreciating from 1994 until the breakdown of the exchange rate band policy in January 1999. Data from Brazilian Central Bank (www.bcb.gov.br).

${ }^{5}$ See Taylor (1994) about gap models and McCombie and Thirlwall (1999) about the relationship between Thirlwall's law and gap models. See also Chenery and Bruno (1962) regarding two gap models.
} 
the capital account surplus after 1994, and of external reserves. Due to an overvalued exchange rate, however, the current account severely constrains the demandpull sectors (consumption, investment, and exports).

As pointed out above, after 1990 there were important changes in long-run policies in Brazil, when inward-oriented policies were changed to outward-oriented policies. The consequences for current account equilibrium were clear. Therefore, the behavior of exports in Brazil can lead to difficulties in long-run growth even when a surplus in the current account appears to show a reasonable short-run dynamic. Hence, financial and trade liberalization can lead to external constraints as long as current account deficits cannot be financed indefinitely. These constraints are particularly problematic in developing countries such as Brazil. The counterargument to this dynamic is that differences in growth rates are determined by differences in labor productivity, Krugman (1989) being one of its most prominent supporters. ${ }^{6}$ Classical theories of international trade highlight liberalization and outward-oriented policies as the best way to guarantee long-run growth. As Edwards (1993) pointed out, openness can lead to technological absorption as long as a foreign source related to absorption of inventions generated in other nations is one of the two origins of total factor productivity growth. The keystone in the strategy of these theories is liberalization as a way of achieving greater productivity and international competitiveness. ${ }^{7}$

As was demonstrated in Brazil, after the financial and trade liberalization, empirical evidence also suggests that openness, or trade and financial liberalization, will not necessarily lead to faster growth or less costly adjustment. Indeed, a positive association between trade liberalization and economic performance is difficult to measure through cross-section or time-series evidence. Taylor (1991) looked into the recent experiences of fifty Third World economies, and found that neither trade openness nor outward orientation is linked to higher growth rates: "fast-growing countries are more or less open, have dispersed patterns of specialization and their success is not obviously led by exports, industrial or otherwise" (Taylor, 1991, p. 103). Moreover, a few fast-growing countries have had rapid export expansion, but that correlation does not extend to the group of developing countries as a whole. ${ }^{8}$

\footnotetext{
${ }^{6}$ Krugman (1989) presents a stylized model similar to Thirlwall (1979) model, although the causal relationship is opposite. For Krugman (1989) income elasticity of exports and imports are related to income. In his model, the 45-degree rule, these elasticities alter as result of economic growth. Indeed, for him, economic growth affects income elasticities of imports and exports. For a critical evaluation of the 45-degree rule see Mc Combie and Thirlwall (1994).

${ }^{7}$ Hecksher-Ohlin-Samuelson model and its extensions. For an empirical estimation of the Total Factor Productivity, see Edwards (1993).

${ }^{8}$ Regarding the effects of trade liberalization on growth, Helleiner (1996) argues, there has been little success with attempts to find statistically significant correlation between trade policies and economic growth. Besides, there is the usual problem of attributing causality (one should consider the possibility that governments routinely tighten restrictions when economic performance becomes worse, which can
} 


\section{THE MODEL OF BALANCE-OF-PAYMENTS CONSTRAINED GROWTH}

\subsection{Thirlwall's Model: General Approach}

Thirlwall's model emphasizes that the Dynamic Harrod foreign multiplier determines long-term economic growth. Thirlwall's model stresses that demand factors induce economic growth. In an open economy, the dominant constraint upon demand is BOP.

The basic idea of Thirlwall's approach highlights how BOP affects the growth performance of countries. As a matter of fact, mainstream versions of economic growth generally neglect not only the demand side of the economy, but also external constraints. Even new growth theories are supply-oriented and, in general, are closed models. Keynesian models along Kaldorian lines, such as Thirlwall's BOPconstrained growth model, link trade to growth because exports pull demand. Indeed, trade represents a crucial constraint to economic growth when there are BOP problems. Static trade models suggest that movements toward openness can temporarily increase the rate of growth due to short-run gains from the reallocation of resources, which would imply a positive relationship between changes in openness and GDP growth. The new growth literature also identifies a number of avenues through which openness might affect long-run growth. ${ }^{9}$ Some of these channels are technological change and technological gaps. The idea behind these new growth models is that countries, which are more backward, actually provide more opportunities to absorb new ideas, and will converge on international norms more quickly, allowing them to benefit from technological change. Nevertheless, even open new endogenous growth models, such as that of Grossman and Helpman $(1990,1991)$, focus only on trade and growth and neglect BOP constraints. A onegap model in the Keynesian and structuralist traditions reveals the demand and external constraints in an open economy.

Indeed, Thirlwall's approach stresses that neither trade and financial liberalization nor strategies of export promotion necessarily lead to better growth performance. The Keynesian and structuralist traditions take into consideration both current account and capital account equilibrium. Therefore, one should consider not only exports of goods and services, but also - and very importantly - the income elasticity of demand for imports. Export performance and income elasticity of demand for imports imply that trade and capital account liberalization do not necessarily lead to economic growth through technological gains or through

create a spurious relationship between distortions and growth). Several others recent studies have demonstrated some difficulties in finding strong relationships between trade liberalization and growth. See, among others, Ocampo and Taylor (1998), Rodriguez and Rodrik (1999), Rodrik (1999) and Harrison and Hanson (1999).

${ }^{9}$ See, for the special relationship between trade and growth using Endogenous Growth, Grossman and Helpman (1990) and Grossman and Helpman (1991). See, also, for an empirical estimation of economic growth across countries Barro (1997). 
an increase in total factor productivity (TFP). Furthermore, export-led growth does not necessarily lead to better economic performance.

A traditional version of Thirlwall's (1979) model can be presented in the following three equations:

$$
\begin{aligned}
& \mathrm{x}=\phi\left(\mathrm{p}_{\mathrm{d}}-\mathrm{p}_{\mathrm{f}}\right)+\rho \mathrm{z} \\
& \mathrm{m}=\alpha\left(\mathrm{p}_{\mathrm{d}}-\mathrm{p}_{\mathrm{f}}\right)+\pi \mathrm{y} \\
& \mathrm{x}+\mathrm{p}_{\mathrm{d}}=\mathrm{m}+\mathrm{p}_{\mathrm{f}}
\end{aligned}
$$

Where $\rho, \pi$, and $\alpha>0$ and $\phi<0$. Income elasticity of exports and imports are $r$ and $p$ respectively, price elasticity of exports and imports are, respectively, $\phi$ and

$\alpha . x$ is the growth rate of real exports, $m$ is the growth rate of real imports, $\mathrm{z}$ is the growth rate of the-rest-of-the-world real income, $y$ is the growth rate of real domestic income, $\left(p_{d}-p_{f}\right)$ is the rate of growth of relative prices (rate of growth of domestic prices less the rate of growth of prices in the rest of the world). Equations (1) and (2) are, respectively, export and import demand functions, whereas equation

(3) is current account equilibrium.

Solving equation (3) for the growth of real income:

$y^{*}=[(1+\phi-\alpha) / \pi]\left(p_{d}-p_{f}\right)+(\rho / \pi) z$

Or, substituting for the growth rate of the world real income, $\mathrm{z}$, from equation (1) yields:

$$
y^{*}=[(1 / \pi)(1-\alpha)]\left(p_{d}-p_{f}\right)+(1 / \pi) x
$$

Supposing that the Marshall-Lerner condition holds or that relative prices are constant if measured in common currency, then $\left(p_{d}-p_{f}\right)=0,(5)$ becomes:

$$
y^{*}=(1 / \pi) x
$$

Equation (6) is BOP-constrained growth, a version of the Harrod foreign trade multiplier. This equation, or Thirlwall's law, states that the higher the income elasticity of demand for imports $(\pi)$ the lower the BOP equilibrium growth rate. ${ }^{10}$

\subsection{A Version for Developing Countries}

Empirical evidence for developed countries shows that this model is an efficient framework for analyzing economic growth in relation to a country's international payments position ${ }^{11}$. However, the model presented above takes into consideration only the current account position. Although in the long term, current

\footnotetext{
${ }^{10}$ As Anwar Shaikh correctly pointed out, Thirlwall's approach does not need to work under current account equilibrium. It is enough that the relationship between exports and imports keeps constant, even if trade balance is in disequilibrium. See Shaikh (1999).

11 See, for example, Atesoglu $(1993,1994,1997)$ for the US experience, Mc Combie and Thirlwall (1994) for a sample of developed countries, Hieke (1997) for the US experience, Atesoglu (1993-94) for Canada, among others.
} 
account equilibrium is extremely important for the BOP position, many developing countries are affected by capital flows. The model must be modified in order to introduce capital flows. Indeed, as McCombie and Thirlwall (1994) point out, "The growth experience of the developing countries over the last thirty years has been even more diverse than that of the developed countries, and can hardly be explained by reference to differences in the autonomous rate of growth of factor supplies." As long as these characteristics are considered, for countries in which capital inflows are important for BOP equilibrium, it is important to include current account imbalance in the model. Clearly, capital flows affect the simple version of Thirlwall's law leading to differences between the growth the law predicts and the effective growth of a country. ${ }^{12}$

We can rewrite equation (3) in order to include capital flows. If the balance of payments is in initial current account disequilibrium, this may be expressed as:

$$
\mathrm{PdX}+\mathrm{F}=\mathrm{Pf} \mathrm{ME}
$$

Where $X$ is the volume of exports, $P_{d}$ is the domestic price of exports, $M$ is the volume of imports, $P_{f}$ is the foreign price of imports, $E$ is the exchange rate, and $F$ is the value of nominal capital flows measured in domestic currency. $F>0$ implies capital inflows and $F<0$ capital outflows. Taking rates of change, it follows:

$$
\delta\left(\mathrm{p}_{\mathrm{d}}+\mathrm{x}_{\mathrm{f}}\right)+(1-\delta) \mathrm{f}=\mathrm{m}+\mathrm{p}_{\mathrm{f}}+\mathrm{e}(8)
$$

Where the subscripts represent the rates of growth of the variables, $\delta$ and $(1 \delta)$ represent the shares of export and capital flows as a proportion of total receipts. Substituting (8) into (1) and (2) and assuming again that the Marshall-Lerner condition holds or that relative prices are constant if measured in common currency, equation (8) becomes:

$$
\mathrm{y}^{*}=\left[\delta \mathrm{x}+(1-\delta)\left(\mathrm{f}-\mathrm{p}_{\mathrm{d}}\right)\right] / \pi
$$

The BOP-constrained growth rate, starting from initial current account imbalance, is the weighted sum of the growth of exports due to exogenous income growth outside the country, and the growth or real capital flows, divided by the income elasticity of demand for imports. The difference between the actual growth rate and that predicted by (6) will be a measure of the pure terms-of-trade effect on real income growth and of any import volume response from relative price changes, relaxing or tightening the BOP constraint on growth according to the direction of movements in the terms of trade and whether the import volume response is normal or perverse. ${ }^{13}$ Regarding these aspects of BOP constraint, three observations are important:

\footnotetext{
12 Brazil is a good example of capital inflows from 1966 to 1979, as well as after 1990.

13 This feature is compatible with the difference between predicted growth rate and effective growth rate in Japan (Thirlwall, 1979). In fact, due to massive surplus in current account, it becomes visible that, in Japan, the effective growth rate is smaller than the balance-of-payments equilibrium growth rate from applying equation (6).
} 
(i) With no equilibrium and no capital flows, equation (9) is equal to equation (6);

(ii) If there is initial current account disequilibrium, but the rate of growth ofnominal capital inflows is zero, it follows;

$\mathrm{y}-\mathrm{y}^{*}=(1-\delta)\left(\mathrm{p}_{\mathrm{d}}+\mathrm{x}\right) / \pi$

Admitting that $p_{d}$ is positive, whereas $y$ is the effective income rate of growth.

(iii) With the initial current account deficit financed by capital inflows,

$\mathrm{f}=\mathrm{p}_{\mathrm{d}}+\mathrm{x}$ and

$y-y^{*}=(1-\delta)\left(p_{d}+x-f\right) / \pi$

And, in real terms, if:

$f-p_{d}>x$ then underpredicted real income growth rate;

$f-p_{d}<x$ then overpredicted real income growth rate;

$f-p_{d}=x$ then unaffected real income growth rate.

\section{ESTIMATING GROWTH CONSTRAINED BY BOP FOR THE BRAZILIAN ECONOMY, 1955-98}

As Hieke (1997) and Atesoglu (1997) stressed, traditional econometric procedures are not sufficient predictors of BOP-constrained growth, even if one estimates equations by means of the first difference. In fact, as the literature of cointegration stresses, estimation of a time series under ordinary least squares (OLS) regression may lead to a spurious regression, and besides, it does not show the long-run relationship between the variables. ${ }^{15}$ Therefore, a cointegration technique is important because it yields more realistic results. Using augmented Dickey-Fuller (ADF) tests, Hieke (1997) demonstrated that for some periods after World War II, Thirlwall's law is not valid for the US economy. Atesoglu (1997) showed that, with the exception of 1943-47 period, the growth rates of exports and of GDP always move together.

Since a cointegration test yields complementary results I will use it to analyze Brazil's economic growth. Our purpose is to determine the order of integration in time series using ADF and Phillips-Perron (PP) tests for variables in equation (6). Since this long-run relationship is verified, we would not reject the hypothesis that Thirlwall's law holds for time-series data on Brazil.

\footnotetext{
${ }^{14}$ An anonymous referee has pointed out that equations (10) and (11) are not useful, since they will not be used in the estimation. Although these equations will not be estimated, they are important to show the effects of capital inflows, or, more specifically, the differences between predicted growth using this model and effective growth. In fact, Brazil demonstrates the importance of capital flows to its economic growth.

15 There is an extensive literature about cointegration and its results for time-series regressions. See, for example, Rao (1994), Maddala and Kim (1998), and Hamilton (1994) among others. A discussion about this technique is out of scope of this work.
} 


\subsection{Empirical Results}

As already pointed out above, the cointegration regression will be used to estimate the model, since the model proposed presents non-stationary variables. A series $\mathrm{x}_{\mathrm{t}}$ is said to be integrated of order $\mathrm{p}, \mathrm{I}(\mathrm{p})$, if it has a stationary ARMA representation after differencing $p$ times. A vector of time series $X_{t}$ is said to be integrated of order p-q, CI (p,q), if (i) all series in the vector are integrated of order $\mathrm{p}$, and (ii) a linear combination of them is integrated of order $\mathrm{p}$-q, where $\mathrm{q}>0$. Supposing the bivariate case, where the vector $\mathrm{X}_{\mathrm{t}}$ consists of $\left(\mathrm{X}_{\mathrm{t}}, \mathrm{Y}_{\mathrm{t}}\right)$, the variables $\mathrm{X}_{\mathrm{t}}$ and $y_{t}$ will be cointegrated if they are integrated of the same order $p, I(p)$, and if there exists a constant $\mathrm{b}$ such that their linear combination $\mu \mathrm{t}$ from

$$
y_{t}=b x_{t}+\mu_{t}
$$

is $\mathrm{I}(\mathrm{p}-\mathrm{q})$. If this is the case, equation (13) is a cointegrating regression and the relationship $y_{t}=b x_{t}$ is a long-run equilibrium relationship, which will tend to be reestablished after a disequilibrium shock. If, on the other hand, the stochastic behavior of $\mu_{t}$ is such that $x_{t}$ and $y_{t}$ are not cointegrated, $x_{t}$ and $y_{t}$ will tend to drift apart in the long run and $x_{t}$ will be of little use in explaining $y_{t}$.

If the variables do cointegrate, the cointegrating regression allows us to estimate the long-run regression coefficients, which are consistent regardless of the dynamic structure of the model, and whether any RHS variables are correlated with the disturbance. These estimates are superconsistent since they converge to their true values at a faster rate than normal OLS estimates. If, however, two series are integrated of different orders they cannot be cointegrated. Therefore, the first step in testing a timeseries model is to determine the order of integration by means of testing for unit roots. The two tests most often used for this purpose are the Dickey-Fuller (DF) and PP tests.

In a univariate time series the basic test for unit roots is to estimate a DF regression, the so-called DF test, when the error terms are independent and identically distributed (iid); when the error terms are not iid then the ADF test is used. The hypothesis that the series has a unit root must be rejected when the DF and ADF statistics have large negative values. These statistics do not have the usual tdistribution under the null hypothesis. In what follows, the critical values of MacKinnon have to be used.

DF and ADF tests admit that the error term is nonspherical. If it is suspected that the errors are autocorrelated or heteroskedastic, PP tests have to be carried out. This procedure consists in calculating the DF statistics, obtaining a t-value by running an auxiliary regression, and, then, adjusting these statistics before consulting the critical values appropriate for that version.

Once the order of integration of the time-series data is determined, the cointegration test can then be performed if variables integrated are of the same order. If variables are found to be $\mathrm{I}(1)$, as it may happen in the exercises that follow, cointegration requires the residuals from cointegrating regression to be $\mathrm{I}(0)$, that is, it requires the residual series from the OLS regressions of the variable in level form to be stationary. The ADF and PP tests must reject the hypothesis of a unit root in the residual series. 
Therefore, the first step is to test for unit roots in each series. The ADF and PP tests will be used to find the presence of unit roots. Holden and Perman (1994) suggest estimating the following equations to test trend and intercept, including sufficient lags to eliminate serial correlation in the regression residual.

$$
\begin{aligned}
\Delta \mathrm{y}_{\mathrm{t}} & =\phi \mathrm{y}_{\mathrm{t}-1}+\alpha+\beta \mathrm{t}+\Sigma \theta \Delta \mathrm{y}_{\mathrm{t}-1}+\varepsilon_{\mathrm{t}}(14) \\
\Delta \mathrm{y}_{\mathrm{t}} & =\phi \mathrm{y}_{\mathrm{t}-1}+\alpha+\Sigma \theta \Delta \mathrm{y}_{\mathrm{t}-1}+\varepsilon_{\mathrm{t}} \\
\Delta \mathrm{y}_{\mathrm{t}} & =\phi \mathrm{y}_{\mathrm{t}-1}+\Sigma \theta \Delta \mathrm{y}_{\mathrm{t}-1}+\varepsilon_{\mathrm{t}}
\end{aligned}
$$

Where $\Delta y t=y t-y t-1$, and $\mathrm{y}$ represents the relevant time series, $\mathrm{t}$ is a linear time trend and $\alpha$ the intercept. The null hypothesis that the time series is non-stationary $(\phi=0)$, i.e., integrated of order one $\mathrm{I}(1)$ or greater, is tested against the alternative hypothesis that the series is stationary $(\phi \neq 0)$, i.e., integrated of order zero $\mathrm{I}(0)$. If the series $y_{t-1}$ has a unit root and the linear time trend is not significant, then the estimated coefficients $\phi$ and $\beta$ should be zero.

Unit root tests, using both PP and ADF tests, were carried out for both variables in equation (6), that is, growth of GNP and growth of exports in Brazil between 1955 and $1998^{16}$, both for levels and first differences of the variables. As used in empirical macroeconometrics, these tests have to be performed using such equations as (14), (15), and (16), that is, (i) trend and intercept, (ii) no trend and intercept, and (iii) no trend and no intercept. ${ }^{17} \mathrm{ADF}$ tests included different lags, while PP tests included only three truncation lags, since the Newey-West test suggests this number. The tests are very responsive to the number of lags included. Indeed, on one hand, PP tests do not reject the null hypothesis that the variables being considered are $\mathrm{I}(1)$ against the alternative that they are $\mathrm{I}(0)$; nor did they demonstrate timetrend significance. ADF tests, on the other hand, tend to be responsive to the number of lags included. Admitting no time trend, since this variable does not show significance different from zero, only with two lags is GDP integrated of order one. Nevertheless, one can admit that both series are I(1) based on PP (3) and ADF (2) tests without time trend. Since the evidence presented above indicates the presence of a single unit root on all series tested, it is possible to perform a cointegration test for the relationship between exports and GDP in Brazil. (See Tables 1, 2, and 3 below.)

\footnotetext{
${ }^{16} \mathrm{Y}$ is the domestic income measured by the GDP in Brazil. Until 1992 it was used the data from Maddison (1995). After that, the source of the data was Conjuntura Economica, FGV, Brazil, several issues. $\mathrm{X}$ is the volume of exports in current dollars (Conjuntura Economica, FGV, Brazil). Maddison (1995) has been chosen because it has a large span of data of GDP and GDP per capita in dollars using PPP. After 1992 I use GDP index from Conjuntura Economica. Although it has been used different source of data, Maddison (1995) is the only available work that presents a large span of data in dollars using PPP. The compatibility of both sources has been made by using an index of GDP after 1992 from Conjuntura Econômica. Despite the tribulations of such methodology, it has the advantage to allow us work in dollars in a long time series.
}

${ }^{17}$ All these tests were performed using Microsoft E-views 3.0. 
Table 1: Test of the Unit Roots (1955-98): Intercept and Trend

\begin{tabular}{ccccc}
\hline Variable & ADF (1) & ADF (2) & ADF (3) & PP(3) \\
\hline $\operatorname{Ln} Y$ & -0.903302 & -1.120362 & -0.426538 & -0.489119 \\
$\Delta \operatorname{Ln} Y$ & -2.339351 & $-3.428789^{* * *}$ & -3.127892 & $-4.528930^{*}$ \\
$\operatorname{Ln} X$ & -1.804405 & -1.298672 & -1.350655 & -1.738924 \\
$\Delta \operatorname{LnX}$ & $-4.386178^{*}$ & -2.670753 & -1.747902 & $-4.399204^{*}$ \\
\hline
\end{tabular}

MacKinnon critical values for rejection of hypothesis of a unit root $-4.18(1 \%),-3.52(5 \%),-3.19(10 \%)$ Significant at $1 \%$ level; ** S ignificant at $5 \%$ level; *** S ignificant at $10 \%$ level

ADF (d) Augmented Dickey-Fuller test, null of Unit roots, lag (d); PP (d) Phillips-Perron test, null of unit root, lag truncation (d). As the Newey-Nest test suggests, PP tests were carried out with only 3 truncation lags.

Table 2: Test for Unit Roots (1955-98): Intercept

\begin{tabular}{ccccc}
\hline Variable & ADF (1) & ADF (2) & ADF (3) & PP(3) \\
\hline $\operatorname{Ln} Y$ & -2.563374 & -1.956296 & -1.884701 & -2.301089 \\
$\Delta \operatorname{Ln} Y$ & -2.339351 & $-2.809652^{* * *}$ & -2.388612 & $-3.714114 *$ \\
$\operatorname{Ln} X$ & -0.373012 & -0.459174 & -1.021253 & -0.180550 \\
$\Delta \operatorname{LnX}$ & $-4.482097^{*}$ & $-2.779593^{* * *}$ & -1.828680 & $-4.47295^{*}$ \\
\hline
\end{tabular}

MacKinnon critical values for rejection of hypothesis of a unit root $-3.59(1 \%),-2.93(5 \%),-2.60(10 \%)$

S ignificant at $1 \%$ level; * S ignificant at $5 \%$ level; *** ignificant at $10 \%$ level

ADF (d) Augmented Dickey-Fuller test, null of unit roots, lag (d); PP (d) Phillips-Perron test, null of unit root, lag

truncation (d). As the Newey-West test suggests, PP tests were carried out with only 3 truncation lags

Table 3: Test for Unit Roots (1955-98): No Intercept or Trend

\begin{tabular}{ccccc}
\hline Variable & ADF (1) & ADF (2) & ADF (3) & PP(3) \\
\hline $\operatorname{Ln} Y$ & 0.981356 & 0.514716 & 0.865864 & 2.387094 \\
$\Delta \operatorname{LnY}$ & -1.568518 & $-1.876316^{* * *}$ & -1.551811 & $-1.973676^{* *}$ \\
$\operatorname{Ln} X$ & -2.379801 & 2.740844 & 1.845455 & 3.446358 \\
$\Delta \operatorname{LnX}$ & $-3.118541^{*}$ & $-1.703846^{* * *}$ & -1.006024 & $-3.488191 \quad *$ \\
\hline
\end{tabular}

MacKinnon critical values for rejection of hypothesis of a unit root $-2.62(1 \%),-1.94(5 \%),-1.62(10 \%)$

* S ignificant at 1\% level; ** S ignificant at 5\% level; ***S ignificant at $10 \%$ level

ADF (d) Augmented Dickey-Fuller test, null of unit roots, lag (d); PP (d) Phillips-Perron test, null of unit root, lag

truncation (d). As the Newey-West test suggests, PP tests were carried out with only 3 truncation lags

The Johansen cointegration test between $\operatorname{LnY}$ and $\operatorname{LnX}$ was carried out admitting a drift (intercept), and no time trend, since this exogenous variable does not show significance different from zero. Holden and Perman (1994) started considering large lags in cointegration tests in order to avoid autocorrelation in the residuals of the cointegrated regression. The optimum lag length is obtained after progressively reducing the lag length based on the significance tests of the parameters. Indeed, the reason for using cointegration is to reduce the lag length to its shortest possible in order to make the model more parsimonious in VAR estimation. After reducing the lag length, the choice of two lags is based on the significance of the parameters, since after that the parameters have not demonstrated significance at $10 \%$. Table 4 presents the results of Johansen cointegration tests for different samples, using two lags for each cointegra- 
tion sample, and assuming no deterministic trend in the data ${ }^{18}$. In all the different periods, the Johansen cointegration test presents positive cointegration between log of GDP and log of exports. It should be noticed that residual tests, not reported, show no autocorrelation in the residual series, and that they show non-stationarity. ${ }^{19}$ The use of different samples in assessing the BOP-constrained model for the Brazilian economy enables us to make some comparisons among different economic policy regimes and exchange rate policy regimes as was pointed out in the last section.

The implicit long-term income elasticity of demand for imports found in every sample is similar to other studies that estimate the income elasticity of demand in Brazil. ${ }^{20}$ For the whole period (1955-98), the implicit income elasticity of demand for imports is 2.38 (representing a coefficient of 0.42 ), and the results show positive and significant cointegration between GDP and exports. For 1955-89 the results do not present a difference from the total sample since the implicit income elasticity of demand for imports is also 2.38 . This behavior suggests that trade liberalization in Brazil after 1990 did not imply changes in income elasticity of demand for imports, and further studies should attempt to demonstrate why. A comparison between 1955-80 and 1981-98 shows that the implicit income elasticity of demand for imports decreased from 2.58 to 2.50, and one might argue that BOP-constrained economic growth in Brazil could not be a result of income elasticity of demand for imports. Nevertheless, if one compares 1966-80 to 1981-98, a period in which the Brazilian economy was more open, one finds that while in the former the parameter was 2.21 , for the latter was $2.58 . .^{21}$ This result suggests that increased income elasticity of demand for imports does explain part of the slowdown in Brazilian economic growth after 1981.

López and Cruz (2000) tested Thirlwall's law to four Latin American countries (Argentina, Brazil, Colombia and Mexico) and found an implicitly income elasticity of demand for imports of 1.6 to Brazil from 1965-1995. They also showed a cointegration between exports and GDP in this period. Like others studies, they claim that this result is sufficient to confirm the validity of the law. However, as it will be shown later, it is necessary to analyze the short-run behavior based on a Vector Error Correction (VEC) model to confirm this hypothesis. In order to establish a causality relation between exports and GDP they tested a Granger causality model. The results show Granger causality from exports to GDP, which is another

\footnotetext{
18 The results using linear trend in the data are similar to no deterministic time trend.

19 The Johansen Cointegration test carried out by E-views 3.0 presents the cointegrated normalized coefficients after certificate that residuals are a white noise. In order to confirm the results, the residuals of each cointegrated equation have been submitted to Engle-Granger procedure. This procedure consists in testing for Unit root and autocorrelation the residual series. Both Breusch-Godfrey Serial Correlation LM Test, and unit root tests have showed there is no correlation in the residuals series of the cointegrated equation. Besides, the presence of an unit root in the residuals was rejected.

${ }^{20}$ See Ferreira (1992) and Azevedo and Portugal (1998).

${ }^{21}$ In fact, between 1955-65, the Brazilian economy was relatively more closed to the subsequent period.
} 
condition to claim that Thirlwall's law is valid. In this paper, however, I achieve different results using a VEC representation. Indeed, as shown above, the causality has not run in the same order demonstrated by López and Cruz (2000).22

López and Cruz (2000) proposed not only to show the validity of Thirlwall's law for some Latin American countries, but also examine the role of exchange rates on trade equations. Their results for Brazil, however, are problematic, since they found that exchange rate depreciation appears to worsen the trade balance. The megasurpluses in 1980s show exactly the opposite behavior. They also claim that the Marshall-Lerner condition was not fulfilled from 1965-1995, which is not a reasonable assumption for a small country. Besides, the behavior of trade surpluses after 1983 in Brazil does not support the hypothesis that the Marshall-Lerner condition was not validate.

Table 4: J ohansen Cointegration Equation for the Relationship between Growth in Exports and Growth in GDP LnY is the dependent variable; No deterministic trend in the data.

\begin{tabular}{ccc}
\hline Sample & Coefficient Ln X & Intercept \\
\hline (1955-98) & 0.419857 & -2.590466 \\
& $(0.01616)$ & $(0.16042)$ \\
& $(25.9742)$ & $(-16.1477)$ \\
\hline$(1981-98)$ & 0.399278 & -2.278520 \\
& $(0.02709)$ & $(0.27847)$ \\
& $(14.7390)$ & $(-8.18239)$ \\
\hline$(1955-89)$ & 0.419875 & -2.599530 \\
& $(0.02175)$ & $(0.20220)$ \\
& $(19.3018)$ & $(-12.8560)$ \\
\hline$(1965-80)$ & 0.387033 & -2.274516 \\
& $(0.03748)$ & $(0.30038)$ \\
& $(10.3272)$ & $(-7.57205)$ \\
\hline$(1966-80)$ & 0.411229 & -2.473456 \\
& $(0.00678)$ & $(0.06958)$ \\
& $(60.6940)$ & $(-35.5502)$ \\
\hline
\end{tabular}

All samples show significant cointegration at $5 \%$.

The values in parenthesis are the standard errors of normalized cointegrating coefficients, and t-statistics.

All of the residuals are integrated of order zero.

Correlation Coefficient of Ln X and LnY: 0.975727.

Two lags were used in the cointegration equation.

${ }^{22}$ It is plausible, however, that different source, as well as different span of the data can explain these different results. 
Using the implicit income elasticity of demand for imports obtained from the cointegrated equation in the whole sample and applying it to equation (6), since the Marshall-Lerner condition holds, it is possible to find the predicted long-run growth in the present model. Figure 1 shows a comparison between the predicted growth, by substituting the coefficient of exports in equation (6), and the effective growth in the period 1955-98 using an eight-year moving average. The differences between the predicted growth and the effective growth can be explained by capital inflows as well as by the difference in relative prices mentioned above in the version of this model for developing countries. Although there are differences between both rates of growth, these series present a reasonable correlation coefficient (0.63). If we discard the period before 1965, when the Brazilian economy was more closed, the correlation coefficient between predicted growth and effective growth rises to 0.91 .

Figure 1 - Growth Predicted by Thirlwall's Law and Effective Growth

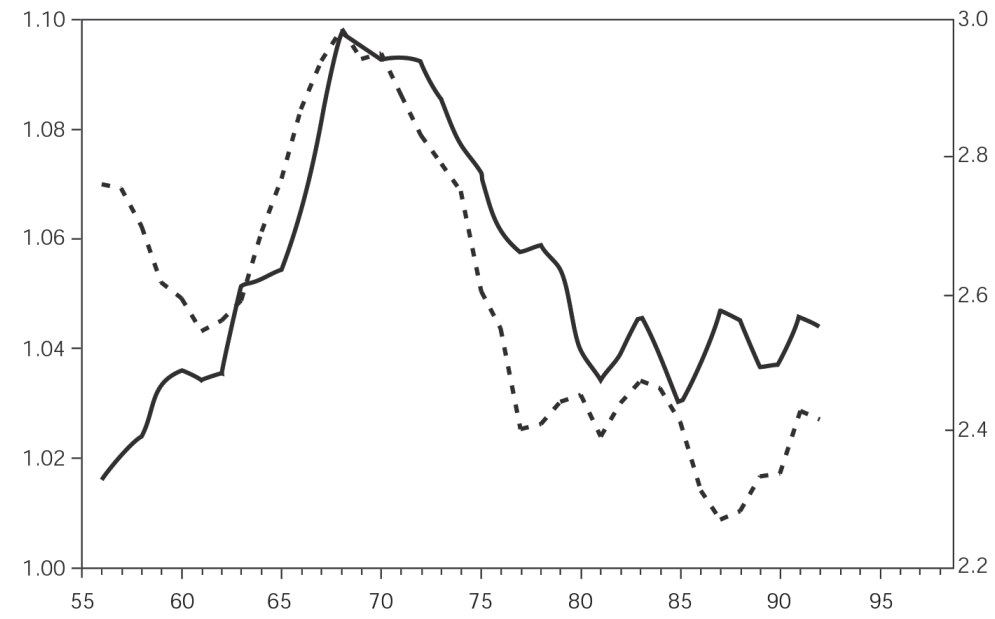

Having performed cointegration tests, both for the whole sample and selected subperiods, and having found the existence of at least one vector of cointegration in each sample between GDP and exports, there is room to suppose that Thirlwall's framework is suitable for understanding external constraints upon growth in Brazil's economy. Some authors, indeed, consider the existence of a single vector of cointegration a sufficient condition to show the validity of Thirlwall's law (Atesoglu, 1997, Moreno-Brid 1998a, among others). If, however, cointegration does not hold between these variables, as Hiecke (1997) found for some periods in the US case, the law is not valid. Although a cointegration can help us to analyze the relationship between GDP and exports, as well as the implicit income elasticity of demand for imports, it seems insufficient since there is no causal relation involved in the cointegration equation. Therefore, a vector error correction (VEC) specification for the same model not only helps to establish a short-run relationship between 
these variables, but also the impulse response functions following an exogenous shock in the error terms of both variables. This fact allows estimating more precisely the causal relation involved among the variables. ${ }^{23}$ Furthermore, the variance decomposition of a VEC gives the relative contribution of an innovation to the meanssquared error of the forecasted variable $b$ periods ahead. These methods can therefore give more accurate results, mainly because the relationship between exports and income elasticity of demand for imports related to GDP probably has bidirectional causality. Yet, assuming that the Harrod foreign multiplier determines the growth of GDP, it seems fair to think that growth in GDP also leads to better export performance, generating a virtuous cycle. The VEC is a VAR that builds in cointegration or, in other words, a restricted VAR.

Supposing the data used in this paper, and for the sake of simplicity admitting no lagged difference terms, the cointegration equation is:

$$
\mathrm{y}_{\mathrm{t}}=\mu+\beta \mathrm{x}_{\mathrm{t}}
$$

Where $\mu$ is the intercept, $y_{t}$ and $x_{t}$ are, respectively, log of GDP and log of exports as already pointed out.

The VEC representation is:

$$
\begin{aligned}
& \Delta y \mathrm{t}=\lambda 1(\mathrm{yt}-1-\mu-\beta \mathrm{xt}-1)+\varepsilon 1, \mathrm{t}(18) \\
& \Delta \mathrm{xt}=\lambda 1(\mathrm{xt}-1-\mu-\beta \mathrm{yt}-1)+\varepsilon 2, \mathrm{t}(19)
\end{aligned}
$$

The estimated coefficients in VEC are difficult to interpret, so that the results can be better summarized by the impulse response functions and variance decomposition of the error covariance matrix. After performing the VEC, for both directions, and assuming two lag lengths, as has already been explained, the results are presented in Table 5. The VEC parameter shows no significance different from zero in the equation where GDP is the dependent variable. When exports is the dependent variable, $74 \%$ of the discrepancy between the short-run value of exports is corrected in the first period. This result suggests, at least in the short-run, that lagged values of exports do not present robustness to explain the growth of GDP $(\triangle \mathrm{GDP}$ in Table 5). On the other hand, lagged values of GDP present statistical significance in explaining the direction of exports for the whole period analyzed (1955-1998). This result reveals also that, in the short run, the causality relation between GDP and Exports presents the opposite direction suggested by Thirwall's framework.

Price effect in the short run can explain this behavior, since particularly in Brazil, exchange rate policy represented important aspect in macroeconomic policy mainly after the debt crisis in early 1980s, as described in the second section of

\footnotetext{
${ }^{23}$ The causal relation can be also tested by means of Granger-causality tests. As a matter of fact, Mehra (1994) pointed out, quoted by Granger (1988), that if a pair of series is cointegrated, then there must be Granger-causation in at least one direction. In a bivariate case, this follows from the observation that such series satisfy an error-correction specification.
} 
this essay. Further research should be carried out to analyze more deeply the shortrun behavior of the variables.

With regard to impulse response functions and variance decomposition, the ordering of the variables affects the results, and so should be chosen carefully. For the sake of this exercise, the choice of order is from exports to GDP, since the aim is to define the pattern of the short-run and long-run effects of exports on growth. The results of the impulse response function and variance decomposition are presented in Figures 2 and 3 and in Tables 6, 7, 8, and 9.

Table 5: Vector error correction estimates for $\triangle$ GDP and $\triangle$ Exports, 1955-1998

Standard deviations and t-statistics in parenthesis

\begin{tabular}{|c|c|c|}
\hline Error Correction & $\triangle \mathrm{GDP}$ & $\Delta$ Exports \\
\hline \multirow[t]{3}{*}{ Cointegration Equation } & -0.041748 & 0.743441 \\
\hline & $(0.05491)$ & $(0.14304)$ \\
\hline & $(-0.76025)$ & (5.19748) \\
\hline \multirow[t]{3}{*}{$\triangle \mathrm{GDP}(-1)$} & 0.547280 & 0.990885 \\
\hline & $(0.15274)$ & (0.39787) \\
\hline & (3.58300) & $(2.49050)$ \\
\hline \multirow[t]{3}{*}{$\triangle \mathrm{GDP}(-2)$} & 0.330682 & 0.122103 \\
\hline & $(0.16166)$ & $(0.42108)$ \\
\hline & $(2.04557)$ & (0.28997) \\
\hline \multirow[t]{3}{*}{$\Delta$ Exports $(-1)$} & 0.042345 & 0.136272 \\
\hline & $(0.04878)$ & $(0.12707)$ \\
\hline & $(0.86802)$ & $(1.07241)$ \\
\hline \multirow[t]{3}{*}{$\Delta$ Exports (-2) } & -0.030887 & -0.346761 \\
\hline & $(0.04697)$ & $(0.12234)$ \\
\hline & $(-0.65763)$ & $(-2.83446)$ \\
\hline R-squared & 0.281189 & 0.528857 \\
\hline Adj R-squared & 0.201322 & 0.476508 \\
\hline Sum sq residuals & 0.046112 & 0.312864 \\
\hline S.E. equation & 0.035789 & 0.093224 \\
\hline Log likelihood & 81.02388 & 41.77247 \\
\hline Akaike AIC & -6.546359 & -4.631656 \\
\hline Schwarz SC & -6.337387 & -4.422684 \\
\hline
\end{tabular}


Tables 6 and 7 and Figure 2 indicate the dynamic responses of exports and GDP. The results illustrate their bidirectional causality. Indeed, as expected, exports affect GDP and GDP affects exports. Table 6 shows that on one hand, GDP's initial response to innovations in exports is positive and tends to increase in intensity, being absorbed after 10 periods. On the other hand, GDP's responses to its own innovations are low at one lag, but tend to increase rapidly and with high intensity until being absorbed after 10-15 periods. This behavior is compatible with the Keynesian and strucuturalist traditions showing that demand pulls economic growth, and that BOP problems constrain growth in Brazil's economy. Table 7 shows the effects of innovations on GDP and exports to exports. A similar pattern of the effects of innovations on GDP is verified. Indeed, the initial dynamic response of innovations in GDP over exports is zero, increasing in intensity after the second period, whereas exports to its own innovations initially decreases in intensity, reversing this behavior and finally being absorbed after 10-15 periods. Once more, the theoretical suppositions of the model built in this paper seem to be in accordance with the empirical pattern in the Brazilian economy.

The variance decomposition of a VEC, as already noted, gives the relative contribution of an innovation to the mean-squared error of the forecasted variables $h$ periods ahead. On one hand, Table 8 shows that after 10 periods, $87.5 \%$ of the forecast error of the GDP is accounted for by its own innovations, whereas $12.45 \%$ is accounted for by innovations in exports. It is worth noting that innovations in exports tend to increase quickly in the first two periods until being absorbed after 10 periods. Table 9, on the other hand, shows the variance decomposition of exports. It reveals that $100 \%$ of the forecast error in the first period is accounted for by its own innovations. After 12 periods, however, $82 \%$ of the forecast error in exports is accounted for by GDP and $18 \%$ by its own innovations.

The VEC, impulse response, and variance decomposition of the model presented show the relevance of the short-run behavior in GDP and exports for the long-run relationship presented in the cointegrated regression for the whole period (19551998). Indeed, these results confirm the importance of BOP-constrained economic growth for long-run economic growth in Brazil. Moreover, it shows that Thirlwall's model, using only cointegration, neglects short-run behavior and is therefore insufficient for demonstrating its empirical validity. The relationship between short-run and long-run behavior allows us to make a better connection in the model, demonstrating the importance of the relationship of exports and income elasticity of demand for imports (in this case represented implicitly by the parameter in the cointegrated equation) to growth and, of course, that of growth to exports. 
Figure 2: Response to Innovations to One $\mathrm{S}$ tandard Deviation Response to One S.D. Innovations
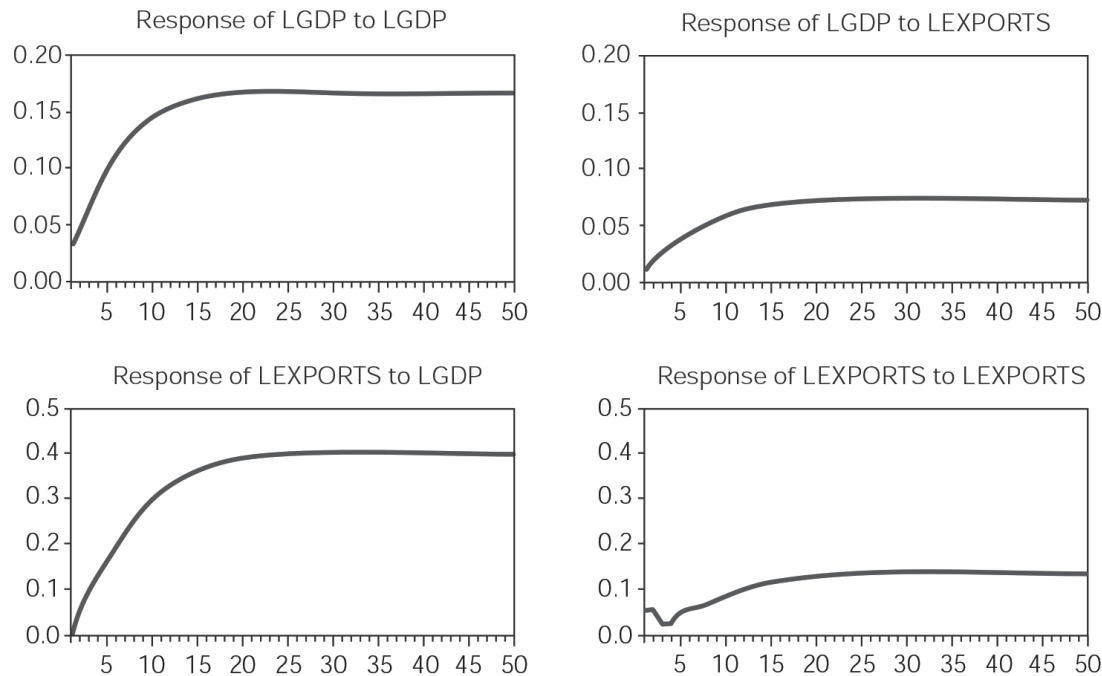

Table 6: Impulse Response to Innovation to One Standard Deviation Response of GDP Ordering Exports -GDP

\begin{tabular}{ccc}
\hline Response period & GDP & Exports \\
\hline 1 & 0.032342 & 0.008869 \\
2 & 0.048692 & 0.018582 \\
5 & 0.099912 & 0.035972 \\
10 & 0.144915 & 0.056889 \\
\hline
\end{tabular}

Table 7 Impulse Response to Innovations to One Standard Deviations Response of Exports

Ordering Exports -GDP

\begin{tabular}{lrc}
\hline Response period & GDP & Exports \\
\hline 1 & 0.000000 & 0.087355 \\
2 & 0.056092 & 0.087373 \\
5 & 0.160805 & 0.080770 \\
10 & 0.293616 & 0.119122 \\
\hline
\end{tabular}


Figure 3: Variance Decomposition
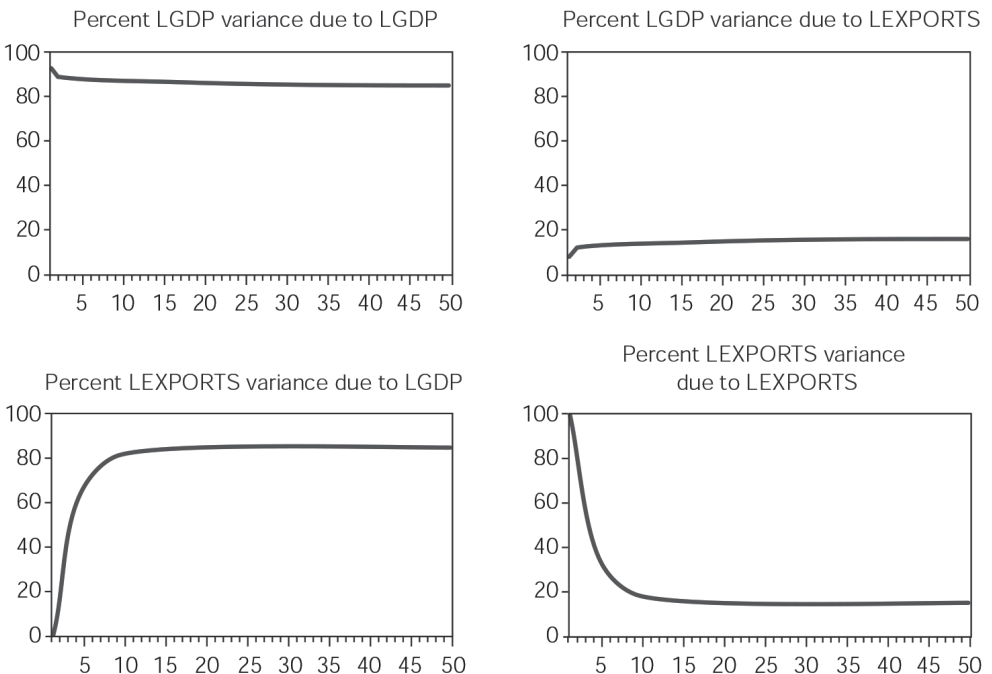

Table 8: Variance Decomposition

\begin{tabular}{cccc}
\hline \multicolumn{4}{c}{ Variance Decomposition of GDP } \\
\hline Period & S.E. & GDP & Exports \\
1 & 0.033536 & 93.00657 & 6.993430 \\
2 & 0.061975 & 88.96215 & 11.03785 \\
5 & 0.169802 & 88.75774 & 11.24226 \\
10 & 0.355561 & 87.54266 & 12.45734 \\
\hline
\end{tabular}

Table 9 Variance Decomposition

\begin{tabular}{cccc}
\hline \multicolumn{4}{c}{ Variance Decomposition of Exports } \\
\hline Period & S.E. & GDP & Exports \\
1 & 12.45734 & 0.000000 & 100.0000 \\
2 & 0.135688 & 17.08914 & 82.91086 \\
5 & 0.291807 & 66.88366 & 33.11634 \\
10 & 0.671431 & 81.88697 & 18.11303 \\
\hline
\end{tabular}

Alexander and King (1998) analyzed the econometric limitations of the available Thirlwall's law tests. They show that the existing cross section studies do not represent an adequate test of balance of payments constrained growth, since these tests can be omitting variables (such profitability of exporting and/or exporter's productivity capacity, among others). The omitted variable bias can produce a false positive result. Their concern relates generally to cross-section econometric studies (Mc Combie and Thirlwall, 1994; Thirlwall 1979). These problems could be solved 
partially by using a time series procedure for countries submitted to test. By performing a cointegration analysis for G7 they have not found evidence to the simple rule of Thirlwall's law. They also tested for price changes and the results are not conclusive. Therefore, they claim that we should be caution with econometric results of Thirlwall's law. Indeed, the authors do not deny the possibility that a country's rate of economic growth may be subject to a long run balance-of-payments constraint. What they suggest is that the simple rule of Thirlwall's law (as seen in equation 6) may have oversimplified the nature of the relationship. This is an important issue that one has to have in mind when working with balance of payments constrained economic growth.

\section{CONCLUDING REMARKS}

In this paper I tested Thirlwall's model on the Brazilian economy using annual data from 1955 to 1998. According to this study, balance-of-payments-constrained growth can be tested using the cointegration technique and a VEC representation. The findings of this econometric exercise provide a satisfactory explanation of variations in the long-term economic growth of Brazil. The Keynesian approach to economic growth can help to make econometric predictions to the development in Brazil. This is important not only because it can help foster longrun growth, but also because in recent history Brazil and other Latin American countries faced episodes of hyperinflation as a result of deficits in the current account and breaks in capital flows.

Although the results indicate the importance of balance of payments-constrained economic growth in Brazil, both for the whole period and for selected periods, one has to be caution with econometric results, as pointed out by Alexander and King (1998). Besides, one cannot guarantee strategies to achieve persistently high economic growth. Indeed, achieving sustainable and stable economic growth depends on strategies that relate institutional and technological policies. This paper only shows the importance of external constraints for long-run economic growth. In addition, the results suggest that a policy of export promotion combined with an import substitution strategy could be rational in terms of policy prescriptions, since both strategies lead to moderate balance-of-payments constraints in the long run.

\section{REFERENCES}

ALEXANDER, R. and Alan KING (1998) "Growth and the Balance of Payments Constraints". Research Paper n. 622. Department of Economics, University of Melbourne, Australia.

ATESOGLU, H. S. (1993) "Balance of Payments Constrained Growth: Evidence from the United States”. Journal of Post Keynesian Economics, Summer.

ATESOGLU, H. S. (1993-4) "Exports, Capital Flows, Relative Prices and Economic Growth in Canada”. Journal of Post Keynesian Economics, Winter. 
ATESOGLU, H. S. (1994) "An Application of a Kaldorian Export-led Model of Growth to the United States". Applied Economics Letters, January.

ATESOGLU, H. S. (1997) "Balance of Payments Constrained Growth Model and its Implications for the United States". Journal of Post Keynesian Economics, Spring, v.19 (3).

AZEVEDO, Andre F.Z. and M. PORTUGAL. (1998) "Abertura Comercial Brasileira e Instabilidade da Demanda por Importações”. Nova Economia, v.8(1). Belo Horizonte.

BARRO, R. J. (1997) Determinants of Economic Growth: A cross-country empirical study. Cambridge, Massachusetts: MIT press.

CASTRO, A.B. \& F.E SOUZA (1985) A Economia Brasileira em Marcha Forçada. Rio de Janeiro, Paz e Terra.

CHENERY, H.B. and Michel BRUNO (1962) "Development Alternatives in an Open Economy: The Case of Israel”. Economic Journal. 72:70-103

Conjuntura Econômica, FGV, Rio de Janeiro, several issues.

EDWARDS, S. (1993) "Trade Policy, Exchange Rates and Growth". NBER Working papers n.4511, Cambridge, Massachusetts, February.

EDWARDS, S. (1998) “Openness, Productivity, and Growth: What Do We Really Know?” Economic Journal, 108 (447): 383-98.

ENGLE, R. \& CLIVER W. J. GRANGER (1987) “Co-integration and Error Correction: Representation, Estimation, and Testing”. Econometrica, 55(2): 251-76

FARGERBERG, J. (1996) "Technology and Competitiveness". Oxford Review of Economic Policy. 12(3). FERREIRA, A. (1992) Trade and Growth: Three Exercises using Brazilian data. Unpublished Ph.D. dissertation, New School for Social Research.

FITZGERALD, E.V.K. \& G. PEROSINO (1996) Trade Liberalization, Employment, and Wages: A critical Approach. (mimeo).

HARRISON, A. (1996) "Openness and Growth: A Time-Series Cross-Country Analysis for Developing Countries". Journal of Development Economics. 48: 419-47.

HARRISON, Ann and GORDON, Hanson (1999) "Who Gains from Trade Reform? Some Remaining Puzzles”. NBER Working Papers 6915, January.

HAMILTON, W. (1994) Time Series Analysis. Princeton, New York.

HELLEINER, G. K. (1994) Trade Policy and Industrialization in Turbulent Times, London: Routledge. HELLEINER, G. K. (1996) Trade, Trade Policy, and Industrialization. (manuscript).

HELPMAN, Elhanan and P. KRUGMAN (1985) Market Structure and Foreign Trade. MIT Press, Cambridge, Massachusetts.

HIEKE, Hubert (1997) "Balance-of-Payments-Constrained Growth: a Reconsideration of the Evidence for the U.S. Economy". Journal of Post Keynesian Economics, Spring, v. 10 (3).

HOLLAND, M., O. CANUTO, and C. XAVIER (1998) "Taxa de Câmbio, Elasticidades-renda e Saldo Comercial na Economia Brasileira". Revista Brasileira de Economia, 52(2) 323-334, Abr/Jun.

HOLDEN D, and R. PERMAN (1994) "Unit Roots and Cointegration for the Economist". In Rao, B. B. (1994). Cointegration for the Applied Economist. Saint Martin Press, New York.

KRUGMAN, P. (1989) "Differences in Income Elasticities and Trends in Real Exchange Rates". European Economic Review. V. 33.

KRUGMAN, P. (1990) Rethinking International Trade. MIT, Boston.

LÓPEZ, Julio G. and Alberto CRUZ B. (2000) “Thirlwall's Law” and Beyond: the Latin American Experience". Journal of Post Keynesian Economics. Spring

MCCOMBIE, J. and THIRLWALL, A. (1994) Economic Growth and the Balance of Payments Constraint. London, St. Martins.

MCCOMBIE, J. and THIRLWALL, A. (1999) "Growth in an International Context: a Post Keynesian View”. In: Deprez, J. and John Harvey. Foundations of International Economics: Post Keynesian Perspectives. London, Routledge.

MCKINNON (1991) "Critical Values for Cointegration Tests”. In Engle, R.F. and Granger, C.W.J. (eds). Long-Run Economic Relationships. Readings in Cointegration. Oxford: Oxford University Press. 
MADDALA, G.S. and In-Moo KIM (1998) Unit Roots, Cointegration, and Structural Change. Cambridge University Press, Cambridge, UK.

MADDISON, A. (1995) Monitoring the World Economy: 1820-1992. OECD, Paris.

MEHRA, Y. P. (1994) "Wage Growth and the Inflation Process: an Empirical Approach". In Rao, B. B. 1994. Cointegration for the applied economist. Saint Martin Press, New York.

MORENO-BRID, J.C. (1998a) “Mexico's Economic Growth and the Balance of Payments Constraints". International Review of Applied Economics, forthcoming.

MORENO-BRID, J.C. (1998b) "On Capital Flows and the Balance-of-payments Constrained Growth Model”. Journal of Post Keynesian Economics, forthcoming.

OCAMPO, J.A. \& TAYLOR, L. (1998) Trade Liberalization in Developing Countries: Modest Benefits but Problems with Productivity Growth, Macro Policies, and Income Distribution. Working papers Series I, n.8. Cepa, New School

RODRIK, Dani (1999) The New Global Economy and Developing Countries: Making Openness Work. Washington, DC. Overseas Development Council.

RAO, B. Bhaskara. (1994) Cointegration for the Applied Economist. Saint Martin Press, New York.

RODRÍGUEZ, F. and RODRIK, D. (1999) Trade Policy and Economic Growth: a Skeptic's Guide to the Cross-National evidence. NBER Working Papers n.5791. Cambridge, Massachusetts. April.

SHAIKH. Anwar (1999) Real Exchange Rates and the International Mobility of Capital. Working paper N. 265. March.

TAYLOR, L. (1991) Income Distribution, Inflation, and Growth, Cambridge MA: MIT Press.

TAYLOR, L. (1994) "Gap Models". Journal of Development Economics, vol. 45, pp. 17-34.

TAYLOR, L. (1993) “Economic Openness: Problems to Century's End”. In Tariq, Banuri. Economic Liberalization: No panacea.

THIRLWALL, A. (1979) "Balance of Payments Constraint as an Explanation of International Growth Rate Differences”. Banca Nazionale del Lavoro Quarterly Review. March, pp. 45-53.

THIRLWALL, A. M. PIANCASTELLI and C. FERNANDES (1981) "Divida Externa e Constrangimento Externo no Brasil”. Revista da Fundação João Pinheiro, Belo Horizonte. 